\title{
SISTEM PENDUKUNG KEPUTUSANPEMILIHAN GURU TELADAN DENGAN SIMPLE ADDITIVE WEIGHTING METHOD (SAW) (STUDI KASUS DI SMA ANGKASA YOGYAKARTA)
}

\author{
Harliyus Agustian, Anton Setiawan Hawibowo, Yuliani Indrianingsih \\ Jurusan Teknik Informatika \\ Sekolah Tinggi Teknologi Adisutjipto Yogyakarta \\ informatika@stta.ac.id
}

\begin{abstract}
Decision Support System or DSS is a system that helps managers solve problems in a semi-structured. Many of the techniques used to make the DSS, one with Fuzzy Logic Multi-Attribute Decision Making (MADM). Fuzzy logic is one problem on feelings. Where the degree of membership is usually representedwith a value of 0 and 1, with Fuzzy Logic is the degree of membership can be represented with a value between 0 and 1, which can be more balanced. High School Angkasa Yogyakarta is a place to educate students thus the students can be useful for Nation.

In realizing, the need for good quality teachers who can become role models for students, so that teaching and learning process will be better. Thus the need assessment conducted by the student or the principal to determine the ability of ateacher, both in the process of teaching or outside the teaching process. In the process of assessment needs to consider several factors than affect teacher performance. These factor related to teaching and learning process outside the process of theaching anyothers on the Indonesian Government Regulation Number 74 Year 2008 about the master of pedagogical,competence, personality, social and professional.

High School Angkasa in conducting an assessment to each teacher based on the result of the vote. So, to help assist in making selection for decision support of teacher to be made SPK. DSS will use fuzzy logic techniques that apply MADM SAW method in its calculation. It is expected that DSS can be an alternativein the selection of exeplary teacher in High School Yogyakarta.
\end{abstract}

Key words: DSS, MADM Fuzzy Logic, SAW method.

\section{Pendahuluan}

Komputer merupakan suatu hasil perkembangan teknologi. Komputer mempunyai kemampuan yang fantastis dalam banyak hal. Dengan kemampuannya itu menyebabkan komputer dapat diterima diberbagai kalangan, bahkan telah menjadi suatu kebutuhan. Salah satu kemampuan itu, adalah dalam pengelolaan data dan komunikasi informasi.

Informasi sangat dibutuhkan dalam proses pengambilan keputusan. Keputusan yang baik dan tepat perlu didukung oleh ketersediaan informasi yang akurat, cepat dan relevan. Dengan informasi yang demikian, supervisor/pimpinan suatu lembaga/organisasi dapat gambaran yang komplek dan spesifik dari suatu keputusan yang akan dirumuskan. Keputusan akan efisien dari aspek waktu karena data dapat diakses secara instan. Di samping itu keakuratan data lebih terjamin, 
sehingga keputusan yang dirumuskan akan lebih tepat dan dapat dirumuskan dalam waktu yang relatif lebih singkat.

Dalam pengambilan keputusan ini, dibutuhkannya suatu sistem pengambilan keputusan yang dapat membantu seorang pimpinan untuk mengambil keputusan. Istilah Sistem Pendukung Keputusan (SPK) atau lebih dikenal dengan Decision Support System (DSS) merupakan suatu sistem untuk mendukung para pengambil keputusan manajerial dalam situasi keputusan semiterstruktur. Sistem ini dimaksudkan untuk menjadi alat bantu bagi para pengambil keputusan untuk memperluas kapabilitas mereka, namun tidak untuk menggantikan penilaian mereka.

SMA Angkasa dalam pengambilan keputusan untuk memilih guru teladan tidak berdasarkan data yang kualitatif yang membandingkan setiap kriteria yang ada, sehingga penilaian hanya dilakukan oleh siswa dengan memilih guru yang menurutnya teladan tanpa mempertimbangkan kriteria-kriteria yang diperlukan. Jadi penilaian yang dilakukan hanya berdasarkan hasil voting suara dan juga perhitungan yang dilakukan juga tidak komputerisasi sehingga data yang lama sering sekali hilang dari pembukuan. Dalam hal ini sangat diperlukan sistem yang dapat menggabungkan antara pendukung keputusan dan komputerisasi dengan menggunakan perhitungan yang tepat, untuk membantu menilai setiap guru berdasarkan kriteria atau faktor yang dijadikan pertimbangan, sehingga hasil yang didapat lebih objektif.

\section{Landasan Teori}

Kualitas dalam pengambilan keputusan sangat dipengaruhi oleh kriteria yang akan digunakan dalam penilaian, semakin detail kriteria yang digunakan hasil keputusan yang didapat akan semakin baik.

Pengambilan keputusan untuk menentukan guru teladan, dalam segi penilaian lebih cenderung ke siswa dan lingkungan sekolah. Sehingga melibatkan data-data yang bersifat kualitatif, seperti interaksi antara guru dengan siswa dan sesama pengajar. Dengan data-data yang bersifat kualitaif tersebut dapat dijadikan acuan dalam pengambilan keputusan untuk mendapatkan hasil terbaik.

\section{Dasar Penilaian Guru}

Kriteria penilaian yang dilakukan meliputi kompetensi pedagogik, profesional, kepribadian, dan sosial yang terdapat di dalam Peraturan Pemerintah Republik Indonesia Nomor 74 Tahun 2008 Tentang Guru. Faktor-faktor tersebut dapat dijabarkan sebagai berikut.

1. Penilaian yang dilakukan oleh siswa melibatkan kompetensi pedagogik, soial dan profesional yang dijabarkan sebagai berikut.

a. Menunjukkan penguasaan materi yang diajarkan

b. Mengaitkan materi dengan pengetahuan lain yang diajarkan

c. Menyampaikan materi dengan jelas

d. Mengaitkan materi dengan realitas kehidupan

e. Melaksanakan pembelajaran secara bertahap / runtut

f. Menguasai kelas

g. Melaksanakan pembelajaran sesuai dengan alokasi waktu yang di rencanakan

h. Menggunakan media secara efektif dan efisien

i. Menghasilkan pesan yang menarik

j. Menumbuhkan partisipasi aktif siswa dalam pembelajaran 
k. Menunjukkan sikap terbuka terhadap respon siswa

1. Menumbuhkan keceriaan dan antusiasme siswa dalam belajar

m. Memantau kemajuan belajar selama proses

n. Melakukan penilaian akhir sesuai dengan kompetensi

o. Menggunakan bahasa lisan dan tulis secara jelas, baik dan benar

p. Berpakaian rapi dan sopan

q. Disiplin dalam mengajar

2. Penilaian oleh kepala sekolah melibatkan kompetensi kepribadian dan sosial yang dijabarkan sebagai berikut.

a. Ketaatan dalam menjalankan ajaran agama.

b. Tanggung jawab terhadap tugas.

c. Kejujuran.

d. Kedisiplinan.

e. Keteladanan.

f. Menunjukkan Etos kerja yang tinggi dalam mengajar.

g. Kemampuan menerima kritik dan saran.

h. Kemampuan berkomunikasi.

i. Kemampuan bekerja sama.

j. Memanfaatkan teknologi informasi dalam pengembangan diri.

3. Penilaian umum melibatkan kompetensi profesional yang djabarkan sebagai berikut.
a. Lomba dan karya akademik
b. Pembimbing siswa
c. Keikutsertaan dalam forum
d. Pendidikan
e. Lama Mengajar
f. Jumlah jam mengajar

\section{Sistem Pendukung Keputusan}

Sistem Pendukung Keputusan atau decision support systems disingkat DSS dapat diartikan sebagai sekumpulan procedure berbasis model untuk data pemprosesan dan penilaian guna membantu para manajer mengambil keputusan (Turban, 2005).

\section{Metode Simple Additive Weighting Method (SAW)}

Konsep dasar metode SAW adalah mencari penjumlahan terbobot dari rating kinerja pada setiap alternatif pada semua atribut (Fishburn, 1967 and MacCrimmon, 1968 dalam buku Kusumadewi, 2006). Metode SAW membutuhkan proses normalisasi matriks keputusan (X) ke suatu skala yang dapat diperbandingkan dengan semua rating alternatif yang ada.

\section{Algoritma SAW}

Pada dasarnya langkah-langkah dalam pembentukan metode SAW dapat dijelaskan dengan algoritma berikut.

Langkah Pertama: Data dalam bentuk bilangan fuzzy dikonversi ke bilangan crisp. Berdasarkan tipe data yang digunakan pada setiap kinerja alternatif-alternatifnya, ada 3 jenis data yang digunakan yaitu :

a. Semua data yang digunakan adalah data fuzzy

b. Semua data yang digunakan adalah data crisp 
c. Semua data adalah campuran atara data fuzzy dan data crisp.

Dalam melakukan perangkingan semua data fuzzy dikonversi ke data crisp, apabila berupa data linguistik maka di konversikan terlebih dahulu ke data fuzzy, baru kemudian dikonversikan ke data crisp (Chen, 1992 dalam buku Kusumadewi, 2006). Langkah Kedua: Membuat matriks keputusan dan vektor bobot.

a. Data fuzzy diinputkan ke dalam suatu matriks

b. Pemberian nilai bobot kriteria untuk membuat tingkat kepentingan kriteria Langkah Ketiga: Melakukan normalisasi matriks.

Normalisasi perlu dilakukan untuk mendapatkan nilai normalisasi antara 0 dan 1 , dimana nilai 0 adalah nilai terendah dan nilai 1 adalah nilai tertinggi.

Langkah Keempat: Membuat perankingan.

Perangkingan diperlukan untuk mendapatkan alternatif terbaik, yang melibatkan nilai normalisasi dan vektor terbobot.

\section{Implementasi Sistem dan Analisa}

Program aplikasi yang mengimplementasikan metode SAW untuk pengambilan keputusan pemilihan guru teladan, memiliki menu utama yang disesuaikan dengan hak akses masing-masing user sebelum melanjutkan ke aplikasi selanjutnya. Menu utama tersebut terdiri atas file untuk master input data yaitu input kriteria, output, alternatif guru yang akan dipilih, siswa dan user. Kemudian proses perhitungan SAW yang dilakukan oleh siswa dan kepala sekolah, sampai ditemukan alternatif terbaik yang akan mendapat predikat guru teladan. Juga terdapat fasilitas edit untuk memperbaiki master input data kriteria dan output. Selain itu juga terdapat fasilitas bantuan untuk admin dan info. Gambar 1 memperlihatkan tampilan form utama.

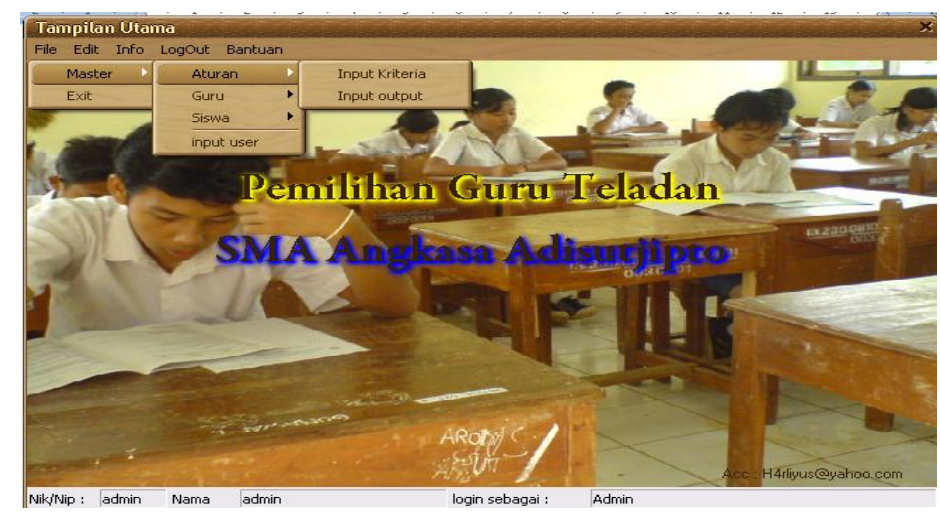

Gambar 1. Form Menu Utama

\section{Form Inputan}

Form penginputan yang sangat dibutuhkan dalam sistem ini adalah penginputan kriteria. Gambar 2 akan memperlihatkan proses penginputan.

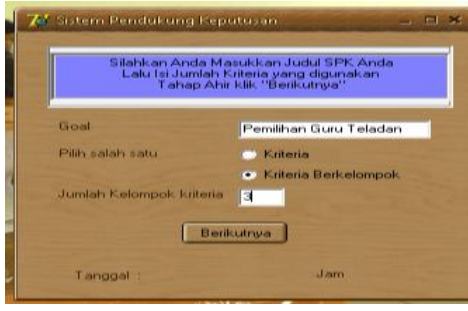

Gambar. 2a

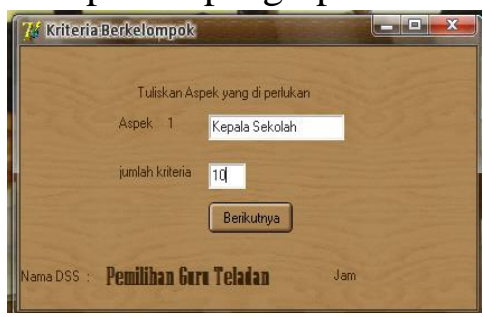

Gambar. 2b 


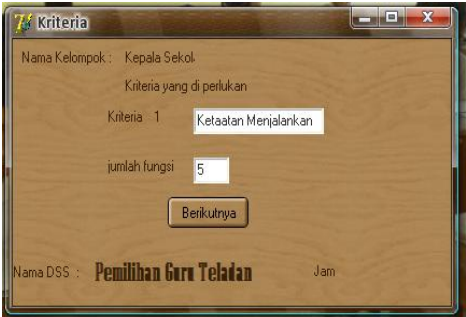

Gambar. 2c

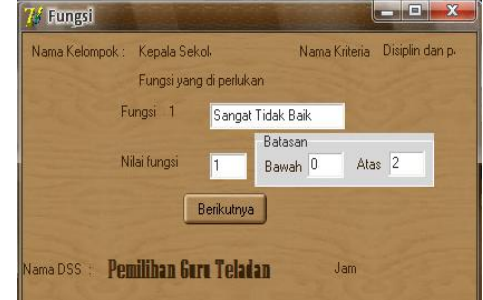

Gambar. 2d

Gambar 2a merupakan proses penginputan nama Projek guru teladan yang akan dibuat sedangkan Gambar 2b merupakan proses penginputan kelompok kriteria yang digunakan yaitu kelompok siswa, kepala sekolah dan umum. Penginputan jumlah kelompok dilakukan pada gambar 2a. Gambar 2c menunjukkan proses penginputan kriteria berdasarkan kelompok kriteria yang digunakan sedangkan gambar $2 \mathrm{~d}$ menunjukkan proses penginputan nilai fuzzy setiap kriteria, dimana penginputan jumlah nilai fuzzy atau fungsi dilakukan pada gambar 2c. Bila telah selesai menginputkan data pada setiap form maka tekan tombol 'Berikutnya'.

\section{Form Proses}

Proses yang terjadi adalah penilaian yang dilakukan oleh siswa, kepala sekolah dan umum, dimana semua kriteria telah diinputkan pada gambar 2c yang telah disesuaikan dengan nama kelompok kriteria masing-masing. Pada menu utama yang hak aksesnya bukan sebagai admin, pilih menu 'Proses' untuk menampilkan form proses penilaian. Gambar 3 akan memperlihatkan proses penilaian tersebut.

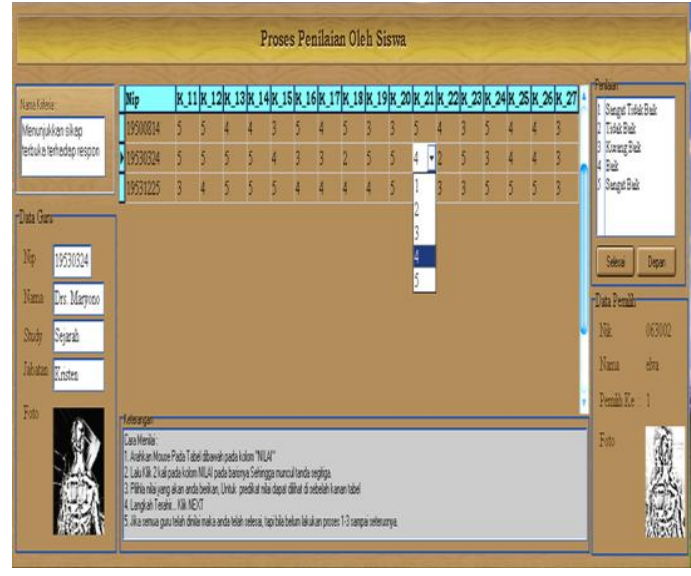

Gambar 3a

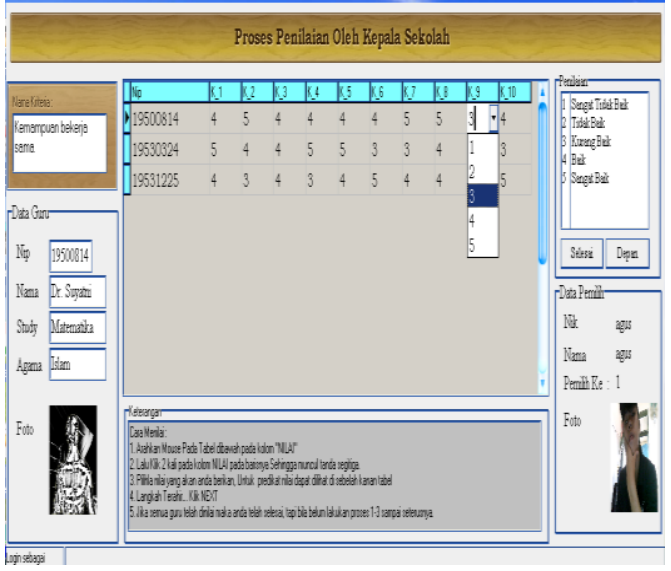

Gambar 3b

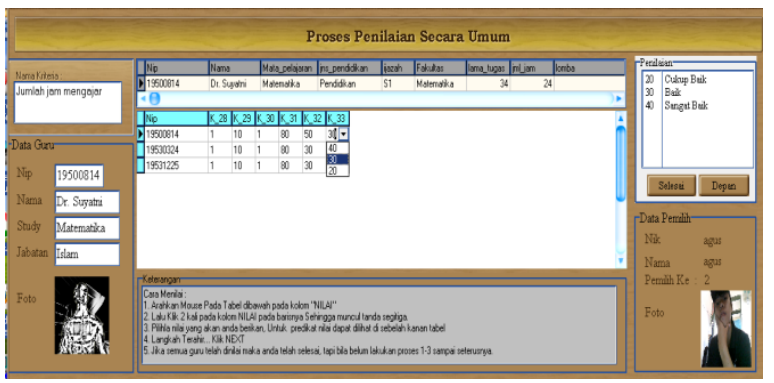

Gambar 3c 
Proses perhitungan pada gambar 3a merupakan penilaian yang dilakukan oleh siswa dengan 17 kriteria penilaian, sedangkan gambar $3 \mathrm{~b}$ merupakan penilaian oleh kepala sekolah dengan 10 kriteria. Kriteria yang digunakan oleh siswa berbeda dengan kriteria kepala sekolah. Proses penilaian sama dengan cara mengisi kolom yang ada untuk setiap alternatif yang ada dengan nilai fuzzy $1-5$ yang memiliki predikat masing-masing dari 'SANGAT TIDAK BAIK' sampai 'SANGAT BAIK'. Langkah terakhir adalah tekan tombol 'Selesai', sehingga akan ditampilkan hasil perhitungan sementara. Berbeda dengan penilaian umum yang menggunakan 6 kriteria yang memiliki nilai fungsi berbeda-beda disesuaikan dengan kondisi SMA. Gambar 3c akan memperlihatkan proses penilaian secara umum.

Pada gambar 3c memperlihatkan data kriteria yang digunakan secara keseluruhan menggunakan portofolio dalam penilaiannya seperti 'Prestasi akademik, Pendidikan (ijazah pendidikan) dll', untuk memberikan nilai pada kolom dan disesuikan dengan data yang ada di atas tabel penilaian yang akan memperlihatkan data portofolio yang telah dilengkapi oleh guru tersebut dan data lainya yang berkaitan dengan kriteria penilaian seperti 'jumlah jam mengajar, lama mengajar dll'. Langkah terakhir tekan tombol 'Selesai' untuk menampilkan hasil penilaian.

\section{Form Hasil Akhir}

Setelah melakukan proses penilaian oleh siswa, kepala sekolah dan umum dengan perhitungan SAW maka akan ditampilkan hasil penilaian secara langsung oleh sistem. Data perangkingan untuk guru teladan didapat dengan membuat persentase penilaian yang dilakukan oleh siswa, kepala sekolah dan umum. Gambar 4 akan menampilkan hasil perhitungan.

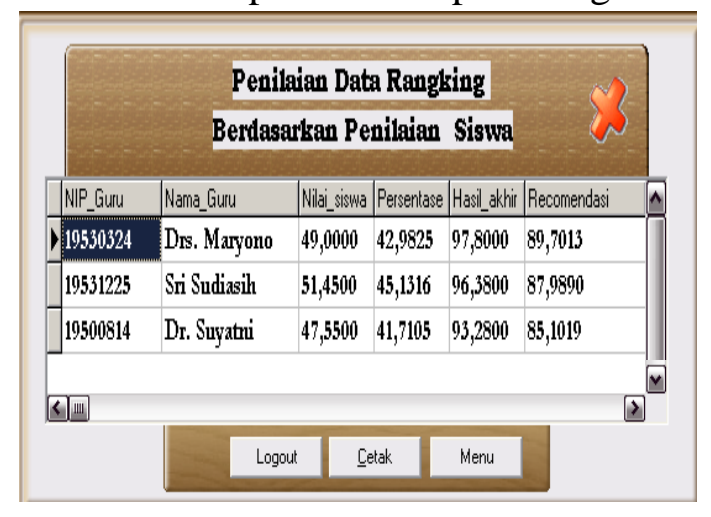

Gambar. 4a

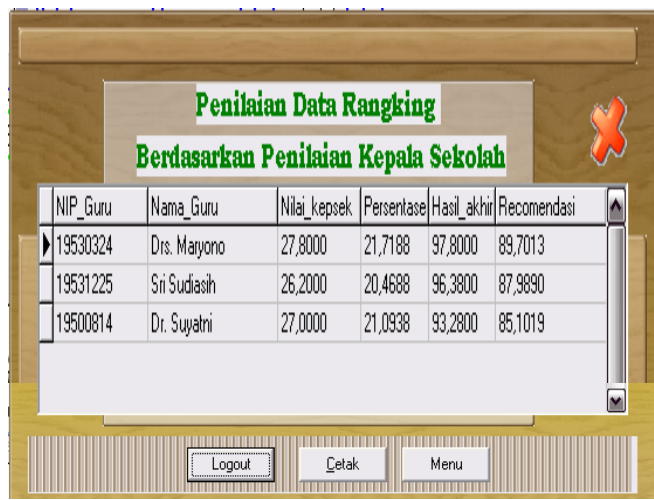

Gambar. 4b

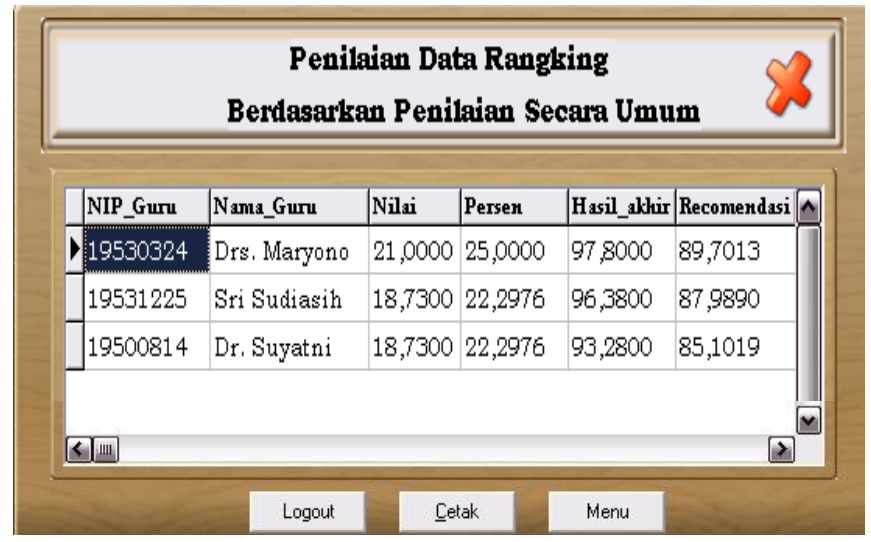

Gambar. 4c 


\section{Analisis}

Pada hasil akhir akan ditampilkan hasil penilaian keseluruhan, dimana pada setiap penilaian yaitu siswa diberikan persentase penilaian $50 \%$, kepala sekolah $25 \%$ dan umum $25 \%$ sehingga total persentase 100\%. Gambar 4a menunjukkan hasil perhitungan yang dilakukan oleh siswa dengan nilai 49 dan persentase 42, 9825 dari persentase keseluruhan 89,7013 di dapat oleh pak Maryono. Gambar 4b menunjukkan hasil perhitungan kepala sekolah dengan nilai 27,8 dan persentase 21, 7188 dari persentase keseluruhan 89,7013 di dapat oleh pak Maryono. Sedangkan gambar 4c untuk umum di dapat oleh pak Maryono dengan nilai 21 dan persentase 25 dari persentase keseluruhan 89,7013. Persentase keseluruhan di dapat dari total persentase penilaian oleh siswa, kepala sekolah dan umum.

\section{Kesimpulan}

Berdasarkan uji coba dan analisis maka dapat diambil kesimpulan :

1. Sistem pendukung keputusan untuk Pemilihan Guru Teladan merupakan solusi bagi para siswa dan kepala sekolah dalam memilih Guru teladan di SMA Angkasa.

2. Konsep simple additive weighting method dapat diterapkan dalam sistem pendukung keputusan untuk pemilihan guru teladan dan menghasilkan nilai yang sama antara perhitungan manual dan sistem.

3. Rekomendasi Pemilihan Guru Teladan dapat tercapai bila melebihi $80 \%$ dari nilai keseluruhan.

4. Proses penilaian akhir didapat dengan memberikan nilai persentase setiap kelompok penilaian.

\section{Saran}

Sistem ini dapat dikembangkan lagi dengan perhitungan yang lainnya misalnya Metode Weighted Product, Electre, TOPSIS dan AHP. Juga aplikasi ini dapat dikembangkan dalam versi client server sehingga dapat dieksekusi oleh banyak user. Selain itu metode-metode ini dapat digunakan untuk memecahkan permasalahan lain selain Pemilihan Guru Teladan.

\section{Daftar Pustaka}

Aqib, Zainal, 2009, Menjadi Guru Profesional Berstandar Nasiona. Yrama Widya, Bandung

Kusumadewi, Sri, Hari Purnomo, 2004, Aplikasi Logika Fuzzy untuk pendukung keputusan, Graha Ilmu, Yogyakarta

Kusumadewi, Sri, Sri hartati, Agus Harjoko, Retantyo Wardoyo, 2006, Fuzzy MultiAttribute Decision Making (Fuzzy MADM), Graha Ilmu, Yogyakarta

Muslich, Masnur, 2007, Sertifikasi Guru Menuju Profesionalisme Pendidik, Grafika Offset, Jakarta

Turban E., Aronson J.E., dkk, 2003, Decision Support Systems and Intelligent Systems (Sistem Pendukung Keputusan dan Sistem Cerdas). Andi Offset. Yogyakarta. 